\title{
The Main Reasons for Emergency Department Visits in Cancer Patients
}

\author{
Kanser Hastalarında Acil Servis Başvurularının Temel Nedenleri \\ (- Emine Bayrak, • Yeter Kitiş * \\ University of Health Sciences, Gülhane Faculty of Nursing, Ankara, Turkey \\ ${ }^{*}$ Gazi University, Faculty of Health Science, Department of Nursing, Ankara, Turkey
}

Abstract

\begin{abstract}
Aim: This descriptive study was conducted to investigate the main reasons for presenting to the emergency department (ED) in a
\end{abstract} university hospital among cancer patients.

Methods: This study was conducted on 243 patients between January 1, 2014 and May 15, 2014. A questionnaire form was used for data collection. Percentage values and mean scores were calculated and a chi-square test was used.

Results: The mean age of the patients was $61.33 \pm 15.33$ years. The most common malignancy was gastrointestinal tract cancers. $64.6 \%$ of patients were admitted the emergency department more than once, $34.4 \%$ of those were readmitted within 0-1 days after discharge. Pain was the most common cause of admission $69.1 \%$ of patients, who were admitted to the emergency department, had recently received chemotherapy before admission. Almost all did not receive home care.

Conclusion: The most frequent emergency department admissions were among patients with progressive cancer. The reasons for emergency department visit among cancer patients, such as pain, nausea and vomiting, and high fever, indicate that post-treatment follow-up and palliative care requirements are not adequately met. We recommend that emergency care guidelines should be established to give better care to cancer patients presenting to emergency department. Furthermore, palliative care services, both at homes and in institutions, should be expanded.

Keywords: Emergency services, cancer, nursing
Amaç: Bu tanımlayıcı araştırma bir üniversite hastanesi acil servisine başvuran kanser hastalarının, başvuru nedenlerini belirlemek amacıyla yapılmıştır.

Yöntemler: Araştırma 243 hastayla, 1 Ocak 2014 ile15 Mayıs 2014 tarihleri arasında yürütülmüştür. Veri toplama aracı olarak anket formu kullanılmıştır. Verilerin değerlendirilmesinde; yüzde ve ortalama değerleri hesaplanmış ve verilerin karşılaştııımasında ki-kare testi kullanılmıştır.

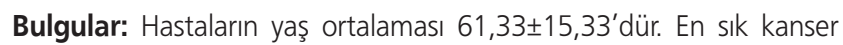
türü gastrointestinal sistem kanserleridir. Hastaların \%64,6'sı acil servise birden fazla başvurmuş, bunların \%34,4'ü 0-1 gün içinde tekrar başvurmuştur. Ağrı başvuru nedenleri arasında ilk sırada yer almaktadır. Hastaların \%69,1'i acile başvurmadan kısa süre önce kemoterapi almıştır. Neredeyse tamamı $(\% 95,9)$ evde bakım almamıştır.

Sonuç: Kanser hastalarından acil servise en sık başvuranlar ilerlemiş kanseri olanlardır. Kanser hastalarının ağrı, bulantı kusma ve yüksek ateş gibi nedenlerle acil servise başvurmaları tedavi sonrası izlem ve palyatif bakım gereksinimlerinin yeterince karşılanamadığını göstermektedir. Acil servise başvuran kanser hastalarına daha iyi bakım vermek için acil bakım rehberi oluşturulmasını, ayrıca evde ve kurumda palyatif bakım hizmetlerinin yaygınlaştııımasını öneriyoruz.

Anahtar Sözcükler: Acil servis, kanser, hemşire

\section{Introduction}

Cancer remains an important public health problem in Turkey as it has been all over the world (1). Cancer is still known as a disease causing chronic pain, lost years of life, and premature death in spite of all the developments in the field of diagnosis and treatment. Classical methods used in its treatment are radiotherapy, chemotherapy, surgical treatment and immunotherapy. Double or triple treatment methods are used together for some cancer types. Treatment period is long and difficult. Patients with cancer experience symptoms caused by the treatment and due to the disease itself. The most significant symptoms
Address for Correspondence/Yazışma Adresi: Emine Bayrak University of Health Sciences, Gülhane Faculty of Nursing, Ankara, Turkey Phone: +90 5395068121 E-mail: eminebayrak2012@gmail.com ORCID ID: orcid.org/0000-0002-3167-5591

Received/Geliş Tarihi: 12 May 2017 Accepted/Kabul Tarihi: 29 June 2017
${ }^{10}$ Copyright 2018 by The Medical Bulletin of University of Health Sciences Haseki Training and Research Hospital
The Medical Bulletin of Haseki published by Galenos Yayinevi.

${ }^{\circledR}$ Telif Hakkı 2018 Sağlık Bilimleri Üniversitesi Haseki Eğitim ve Araştırma Hastanesi Haseki Tıp Bülteni, Galenos Yayınevi tarafından basılmıştır. 
are pain, nausea, vomiting, shortness of breath, fever, weakness, and fatigue (1-3). Approximately $33 \%-50 \%$ of patients feel pain and it is not kept under control in more than $40 \%$ of patients (4-7). Due to the insufficiency of alternative service models for cancer patients, patients and their families are stuck between hospital and emergency department (ED) with the purpose of symptom control during the treatment period $(2,3,8,9)$.

Individuals with chronic diseases visit ED during the exacerbation periods or due to other acute conditions independent of their chronic diseases (8). On the other hand, cancer patients visit ED for some reasons related with cancer, such as pain or other reasons, e.g. infection, undernutrition and insufficient care $(8,10)$. In a systematic review including six prospective and 12 retrospective descriptive studies investigating ED visits for symptom assessment in adult oncology patients, it has been determined that the symptoms seen in these patients were undernutrition, constipation, diarrhea, bleeding, nausea-vomiting, fever, respiratory problems, anxiety, tiredness, pain, anuria/dysuria, infection, etc. (2). Most of the reasons directing cancer patients to ED are treatment side effects experienced after treatment (3). It has been shown that $32.5 \%$ of ED visits could be prevented (10).

Considering the symptoms that patients might experience during the course of treatment, close monitoring of patients will reduce the frequency of ED presentation (10-12).

EDs are providing care to larger number of patients and often overcrowded. Priority may be given to patients with accident injury, bleeding, cardiac and respiratory problems for medical intervention in the triage classification. Thus, the environment may not be very favorable for cancer patients with urgent care needs (13).

Cancer treatment is provided in the outpatient setting unless otherwise is required. Lack of home health care services for cancer patients results in ED presentations or primary care hospitals visits for cancer treatment-related problems.

Thus, this study aimed to identify the reasons for ED visits among cancer patients and to provide suggestions for the development of special services to be offered to cancer patients.

\section{Methods}

This is a descriptive study carried out with cancer patients who were admitted to the ED at a university hospital between January 1, 2014 and May 15, 2014.

The Emergency Severity Index (ESI) was used in all patients admitted to the ED where the study was carried out. The ESI is a five-level ED triage algorithm providing clinically relevant stratification of patients on the basis of acuity and resource needs. Cancer patients are usually given the third code according to the ESI and are often taken to observation rooms or intervention unit. Intervention unit is the place where critical patients can be followed by close monitoring. At the other side, observation rooms (13 in total) are located where doctors and nurses desks are found, covered with transparent glasses, equipped with necessary instruments and separated by walls. Resuscitation/trauma, observation rooms and intervention unit are located in this section of ED. Eleven staff (three emergency medicine assistants, four nurses, one emergency medicine specialist and three attendants) usually provide emergency health services and they work in shifts. This shift plan was accepted as a standard protocol for the Emergency Department of the Medical Faculty of Gülhane.

The study included 243 participants (196 patients' relatives and 47 patients completed the questionnaire). Patients, who were not in the terminal period and who were able to communicate, were included in this study. Patients or patient's relatives who refused to participate in the study (26 patients) and those who died during the study period (14 patients) were excluded.

The data were collected by the researcher (EB) using a questionnaire $(2,3,8,9,13-17)$. The questionnaire consisted of 21 questions (six questions on the demographic characteristics, nine about the treatment and disease, five questions about the reason and frequency of ED visits, and one question about home-care).

The data were collected by the researcher through face-to-face interviews at the ED between the hours 08:00 and 22:00. The completion of the questionnaire took about 10 minutes. The researcher met each patient after the completion of his/her emergency treatment. In the cases where the questions were not answered by the patient due to tiredness or unwillingness, the relative of the patient filled the questionnaire.

\section{Statistical Analysis}

SPSS 16.0 was used for data analysis. In addition to the descriptive statistics; a chi-square test was used for comparisons.

\section{Results}

The demographic characteristics of the participants were as follows: the average age was $61.33 \pm 15.33$ years and $58 \%$ of patients were older than 61 years. $56.4 \%$ were male, $51.8 \%$ were primary or secondary school graduates, and $79.8 \%$ were married. Housewives constituted the $33.3 \%$ and $43.6 \%$ were retired. $45.3 \%$ reported to have 
insufficient family income. $54.3 \%$ of the patients had a comorbid disease. Hypertension was the most common complaint with the incidence of $65.9 \%$. Gastrointestinal tract cancer was the most common cancer (34.2\%); $45.7 \%$ of patients were diagnosed more than one year ago. $50.6 \%$ of patients had metastases. $84.0 \%$ received chemotherapy; $50.2 \%$ underwent surgery and $43.2 \%$ received radiotherapy. Majority of these patients (69.1\%) received chemotherapy before their last visit to ED. $34.2 \%$ of patients were treated in the hospital in the past seven days before visiting ED. $59.3 \%$ of patients were not informed about the possible emergency situations that can occur after treatment. $60.6 \%$ of patients were informed only about probability of fever (Table 1). 35.4\% of patients were admitted to the ED for the first time, and $28.4 \%$ visited ED five times or more. Most of the recurrent admissions were done in the past one week before data collection. The most frequently encountered reason for ED visit was pain (24.3\%). 58\% of patients did not consult

\begin{tabular}{|c|c|c|}
\hline & $\mathbf{n}$ & $\%$ \\
\hline \multicolumn{3}{|l|}{ Comorbid diseases $(n=243)$} \\
\hline Yes & 132 & 54.3 \\
\hline No & 111 & 45.7 \\
\hline \multicolumn{3}{|l|}{ Diseases $(n=132)^{a}$} \\
\hline Hypertension & 87 & 65.9 \\
\hline Diabetes mellitus & 47 & 35.6 \\
\hline Coronary Artery disease & 28 & 21.2 \\
\hline Heart failure & 24 & 18.2 \\
\hline Chronic Obstructive Pulmonary disease & 20 & 15.2 \\
\hline $\begin{array}{l}\text { Other (chronic renal failure and cerebrovascular } \\
\text { accident) }\end{array}$ & 14 & 10.6 \\
\hline \multicolumn{3}{|l|}{ According to the cancer types $(n=255)^{b}$} \\
\hline Gastrointestinal cancers & 83 & 34.2 \\
\hline Respiratory system cancers & 50 & 20.6 \\
\hline Urogenital system cancers & 35 & 14.5 \\
\hline Endocrine system cancers & 35 & 14.5 \\
\hline Hematopoietic system cancers & 25 & 10.3 \\
\hline Musculoskeletal system cancers & 13 & 5.3 \\
\hline Other (nervous system and skin cancers) & 14 & 4.8 \\
\hline \multicolumn{3}{|c|}{ The passing time after the diagnosis of cancer $(n=243)$} \\
\hline $0-3$ months & 75 & 30.9 \\
\hline 4-11 months & 57 & 23.4 \\
\hline 1 year or more & 111 & 45.7 \\
\hline \multicolumn{3}{|l|}{ Metastasis status $(n=243)$} \\
\hline Yes & 123 & 50.6 \\
\hline No & 120 & 49.4 \\
\hline
\end{tabular}

any physician or health department before presenting to ED (Table 2).

Almost all the patients (95.9\%) did not receive health care at home. $51.8 \%$ of patients, who had received chemotherapy, visited ED three times or more. There was no statistically significant difference in treatment methods between patients who visited ED ( $p>0.05)$. Patients with metastases who visited ED three times or more (60.2\%) and $40 \%$ of patients who presented to the ED three times or more were diagnosed with cancer in the past three months. There was a statistically significant difference in time elapsed between patients with newly diagnosed and metastatic cancer $(p<0.05)$ (Table 3$)$.

\section{Discussion}

It is known that most of the ED visits are preventable. In a study carried out in Akdeniz University (14), it was

\begin{tabular}{|c|c|c|}
\hline \multicolumn{3}{|l|}{ Type of treatment $(n=444)^{a}$} \\
\hline Chemotherapy & 204 & 84.0 \\
\hline Surgical treatment & 122 & 50.2 \\
\hline Radiotherapy & 105 & 43.2 \\
\hline Immunotherapy & 13 & 5.3 \\
\hline \multicolumn{3}{|l|}{ The last received treatment $(n=243)$} \\
\hline Chemotherapy & 168 & 69.1 \\
\hline Other treatments except chemotherapyc & 75 & 30.9 \\
\hline \multicolumn{3}{|l|}{ The most recent treatment time } \\
\hline 1 day ago & 34 & 14 \\
\hline 2-7 days ago & 54 & 22.2 \\
\hline 8 days to 1 month ago & 75 & 30.9 \\
\hline 2 months- 1 year ago & 43 & 17.7 \\
\hline Over 1 year & 37 & 15.2 \\
\hline \multicolumn{3}{|c|}{ Informational status of patients about emergency states $(n=243)$} \\
\hline Informed & 99 & 40.7 \\
\hline Not informed & 144 & 59.3 \\
\hline \multicolumn{3}{|l|}{ Informed situations $(\mathrm{n}=99)^{\mathrm{a}}$} \\
\hline Fever & 60 & 60.6 \\
\hline Nausea and vomiting & 51 & 51.5 \\
\hline Pain & 23 & 23.2 \\
\hline Fainting & 8 & 8.1 \\
\hline Diarrhea & 7 & 7.1 \\
\hline Shortness of breath & 6 & 6.1 \\
\hline Loss of balance & 5 & 5.1 \\
\hline Other situations $^{d}$ & 10 & 10.1 \\
\hline \multicolumn{3}{|c|}{$\begin{array}{l}\text { a: " } n \text { " is folded because patients have multiple chronic diseases, b: " } n \text { " is folded } \\
\text { because patients have multiple cancer types, c: Other treatments except } \\
\text { chemotherapy: Radiotherapy, surgical treatment, immunotherapy, d: Other } \\
\text { situations: palpitation, inability to urinate, hemorrhage through the urine tract, } \\
\text { constipation, hemorrhage through the mouth }\end{array}$} \\
\hline
\end{tabular}


claimed that $47 \%$ of the reasons for ED presentation were not due to serious causes. In their study, Yaylacı et al. (9) reported that $81 \%$ of ED visits were oncology-related. ED visit is upsetting for cancer patients and their relatives. Setoguchi et al. (18) defined benchmark measures of quality of cancer care at the end-of-life. One of them was the proportion of patients who had >1 ED visit. In a study

\begin{tabular}{|c|c|c|}
\hline & n & $\%$ \\
\hline \multicolumn{3}{|c|}{ The number of emergency department visits in the past year $(n=243)$} \\
\hline 1 & 86 & 35.4 \\
\hline 2 & 23 & 9.5 \\
\hline 3 & 42 & 17.2 \\
\hline 4 & 23 & 9.5 \\
\hline 5 and more & 69 & 28.4 \\
\hline \multicolumn{3}{|c|}{$\begin{array}{l}\text { The duration between the previous and last admission in the } \\
\text { repeated admissions }(n=157)\end{array}$} \\
\hline 0-1 days & 54 & 34.4 \\
\hline 2 days -1 week & 36 & 22.9 \\
\hline 1 week to more & 67 & 42.7 \\
\hline \multicolumn{3}{|c|}{ Current reason for admission $(n=243)$} \\
\hline Pain & 59 & 24.3 \\
\hline Nausea and vomiting & 40 & 16.5 \\
\hline Shortness of breath & 38 & 15.6 \\
\hline Fever & 29 & 11.9 \\
\hline Weakness & 22 & 9.1 \\
\hline Other complaints ${ }^{\mathrm{a}}$ & 55 & 22.6 \\
\hline \multicolumn{3}{|c|}{ Previous reason for admission $(n=157)$} \\
\hline Pain & 53 & 33.8 \\
\hline Nausea and vomiting & 25 & 15.9 \\
\hline Shortness of breath & 22 & 14.0 \\
\hline Fever & 15 & 9.6 \\
\hline Weakness & 14 & 8.9 \\
\hline Other complaints ${ }^{b}$ & 28 & 17.8 \\
\hline
\end{tabular}

Previous applications to another institution or person before admission to emergency $(n=243)$

\begin{tabular}{|l|l|l|}
\hline No application & 141 & 58 \\
\hline Admitted to the oncology doctor & 39 & 16 \\
\hline Contacted the family doctor or clinic & 38 & 15.7 \\
\hline Received telephone counseling & 25 & 10.3 \\
\hline
\end{tabular}

a: Other complaints: loss of appetite, visual hallucinations, seizures, hemoptysis, palpitations, abdominal swelling, rectal hemorrhage, hypoglycemia, loss of balance, inability to urinate, constipation, body rash, convulsions, slurred speech, hematuria, diarrhea

b: Other complaints: hematuria, diarrhea, loss of appetite, seizures, hemoptysis, palpitations, slurred speech, rectal bleeding, hypoglycemia. Cough, loss of balance, inability to urinate, constipation, body rash by Yıldırım and Tanrıverdi (19), it was reported that $60 \%$ of cancer patients visited ED at least once within one month before death.

Non-communicable diseases (cardiovascular diseases, cancers, chronic asthma, and diabetes) are the top cause of death in Turkey as in the world $(20,21)$. In a study by Barbera et al. (15), it was found that the frequency of ED visit was higher in patients with comorbid diseases than in those without any comorbid disease (15).

It has been reported that the most common comorbid diseases in cancer patients were diabetes and hypertension, similar to that in the current study (Table 1) $(10,22,23)$. Cancer patients with comorbid diseases have poorer survival compared to those without comorbidities (24).

Mayer et al. (13) reported 13 raw chief complaints for $E D$ visits one of them being cancer. Cancer patients visit ED mostly for symptoms related with cancer treatment and this constitutes $5.6 \%$ of all ED visits (10).

In our study, it was determined that approximately half of the patients received the diagnosis one year ago or before and half of them had metastases. Presentation to ED may be an indication of far metastases clinically in patients with gastrointestinal and lung cancer (3).

Table 3. Distribution of metastasis status, the last received treatment and the passing time after the diagnosis of cancer according to numbers of admission to emergency $(n=243)$

\begin{tabular}{|c|c|c|c|c|c|c|}
\hline & \multicolumn{6}{|c|}{ Number of admissions } \\
\hline & \multicolumn{2}{|c|}{$\begin{array}{l}\text { One } \\
\text { admission } \\
(n=86)\end{array}$} & \multicolumn{2}{|c|}{$\begin{array}{l}\text { Two } \\
\text { admission } \\
(\mathrm{n}=23)\end{array}$} & \multicolumn{2}{|c|}{$\begin{array}{l}\text { Three } \\
\text { and more } \\
\text { admission } \\
(n=134)\end{array}$} \\
\hline & $\mathbf{n}$ & $\%$ & $\mathbf{n}$ & $\%$ & $\mathbf{n}$ & $\%$ \\
\hline \multicolumn{7}{|c|}{ The last received treatment } \\
\hline Chemotherapy & 63 & 37.5 & 18 & 10.7 & 87 & 51.8 \\
\hline \multirow[t]{2}{*}{$\begin{array}{l}\text { Other treatments } \\
\text { except chemotherapy }\end{array}$} & 23 & 30.7 & 5 & 6.6 & 47 & 62.7 \\
\hline & \multicolumn{6}{|c|}{$x^{2}=2.695 ; p=0.260$} \\
\hline \multicolumn{7}{|l|}{ Metastasis status } \\
\hline Yes & 42 & 34.1 & 7 & 5.7 & 74 & 60.2 \\
\hline \multirow[t]{2}{*}{ No } & 44 & 36.7 & 16 & 13.3 & 60 & 50.0 \\
\hline & \multicolumn{6}{|c|}{$x^{2}=4.995 ; p=0.082$} \\
\hline \multicolumn{7}{|c|}{ The passing time after the diagnosis of cancer } \\
\hline $0-3$ months & 32 & 42.7 & 13 & 17.3 & 30 & 40.0 \\
\hline 4-11 months & 20 & 35.1 & 4 & 7.0 & 33 & 57.9 \\
\hline \multirow[t]{2}{*}{1 year or more } & 34 & 30.6 & 6 & 5.4 & 71 & 64.0 \\
\hline & \multicolumn{6}{|c|}{$x^{2}=13.797 ; p=0.008$} \\
\hline
\end{tabular}


Most of the patients presenting to ED have gastrointestinal or respiratory tract cancer and this result is compatible with the literature $(3,19,25)$. The main complaints of cancer patients vary according to the type of cancer. While respiratory complaints in patients with lung cancer are more common, complaints in other patients include pain, respiratory and gastrointestinal problems (16). In a study by Kocak et al. (8) carried out with cancer patients who visited the ED in a university hospital within the first three months of the year 2007, it was found that most of the patients had lung cancer and respiratory problems. In a study by Baser et al. (26) including patients with lung cancer presenting to ED, it was determined that the presenting complaint was dyspnea in $62 \%$ of patients, cough in $29 \%$, chest pain in $22 \%$, palpitation in $18 \%$, fever in $13 \%$, and neurological findings in $11 \%$ of patients. In a systematic review including six prospective and 12 retrospective descriptive studies carried out by Vandyk et al. (2), it was determined that the most common cancer treatment- or disease-related symptoms were febrile neutropenia, infection, pain, fever, and nausea/vomiting. In our study, the main reason for ED visits was pain as in the studies by Yaylacı et al. (9) and Barbera et al. (15).

In the literature, pain is the chief reason for ED visits in cancer patients $(3,9,10,27)$. It was stated by Vallerand et al. (4) that there was a positive correlation between metastasis and pain level. In our study, it was found that the most common reason for ED visit in cancer patients was pain $(24.4 \%)$ similar to that in other studies. As these findings show that pain management in cancer patients should be more effective and the staff of ED should be equipped to manage pain. In addition, it would be wise to refer cancer patients presenting with pain to the related departments for the assessment of metastasis.

It has been reported that at least $10 \%$ of individuals who frequently visit ED were cancer patients $(10,15-17)$. It was determined by Minami et al. (16) in a study conducted with lung cancer patients that 1/3 of patients presented to ED for the first time, others visited ED twice or more within one week in after hours on weekdays, weekends, or holidays. We evaluated the whole study group based on 24-hour period in our study, not as an after hours protocol like in the study by Minami et al. (16), we found that 1/3 of cancer patients (34.4\%) repetitively visited ED within 0-1 days. This finding highlights the insufficiency of ED for cancer patients.

Pain is an important factor which decreases the quality of life (28). Pain management centers in Turkey mostly exist in university hospitals and metropolitan cities. Pain management centers are the places where the pain control methods are applied to patients by a multidisciplinary team. Invasive methods are also used in these centers with pharmacological methods. Frequent presentation to EDs is due to the fact that the number of pain centers is limited and pain management in patients with cancer is not sufficient.

In the current study, other common reasons, such as nausea-vomiting, fever and tiredness, were found to be the problems that cancer patients face frequently (Table 2). In their study, Bozdemir et al. (3) reported that pain, shortness of breath, and nausea-vomiting were the most frequent complaints in patients visiting ED. Another symptom is weakness seen in late stage-cancer cases and after medical treatment cures (29).

The most common treatment method for cancer is chemotherapy (30). In our study, most of the patients received chemotherapy (84\%). In a study by Ahn et al. (31) carried out in an ED unit for cancer with eighteen beds in Korea, it was found that 5.502 patients visited the unit in 2010 and, it was determined that $90.8 \%$ of patients were receiving chemotherapy. The most common side effects of chemotherapy are weakness, fatigue, nausea-vomiting, poor appetite, diarrhea, constipation, alopecia, weight loss, mouth sores, insomnia, and muscle pain $(15,22,32,33)$. Patients visit ED due to chemotherapyrelated complications (34). In a study by Livingston et al. (35), the most common ED discharge diagnoses were neutropenia, nausea-vomiting and dehydration, abdominal pain and fever, respectively. In a study by Courtney et al. (36) including patients who were admitted to ED due to febrile neutropenia, it was determined that $75 \%$ of patients were undergoing chemotherapy during the study (36). In a study by Gultekin and Boztas (34), it was determined that ED visits were more common in patients receiving chemotherapy. It has been determined that most of the ED visits were during the treatment and repetitive presentations occurred during chemotherapy $(10,16)$. In a study by Tsai et al. (10), it was determined that two third of ED visits were among patients receiving chemotherapy. There was no difference between patients treated with chemotherapy and other treatments methods in the last year in terms of the number of ED admission $(p>0.05)$. The findings of this study are similar to those in the literature as $69.1 \%$ of patients received chemotherapy before presenting to ED (10).

EDs are the health units for the management of acute problems. They are not sufficient for cancer treatment (13). Cancer patients often experience delays in time to being seen by a physician in EDs. Priority may be given to those with accident injury, bleeding and cardiac and 
respiratory problems in the triage classification. Febrile neutropenia which is a life-threading complication of chemotherapy may end up with sepsis, septic shock and death. Infections occurring due to neutropenia are a risk for patients who are delayed in ED (36).

On the other hand, there are some observations related to the attitudes of health professionals: reluctance to use strong opioids by physicians, administration of analgesics after lengthy delays, and not performing a formal pain assessment using a pain scale (37). In their study, Jain et al. (37) reported that $65 \%$ of 100 cancer patients presenting to ED due to pain reported severe pain and $35 \%$ moderate pain. They found that only five of 88 patients with severe pain were fully adherent to prescribed analgesics. In addition, only four patients were prescribed a strong opioid despite severe pain.

It is important to increase the quality of life of patients with chronic diseases as well as expanding life expectancy. Palliative nursing applications are useful in increasing quality of life (24). Palliative care institutions and homecare facilities are limited in Turkey $(38,39)$, while home-care nursing facilities are common in many European countries. A study in Spain assessed the different nursing models and cancer patients' quality of life and it was determined that the physical and mental status of patients who received nursing care at their home were satisfactory (40).

\section{Study Limitations}

Since some cancer patients who were admitted to the ED could not answer the questions, the interviews were performed with the primary caregivers. This can be considered as a limitation of the study. The fact that the work was done in an ED was another limitation of the research.

\section{Conclusion}

The symptoms in cancer patients increase their frequency of ED visits and, negatively affect their quality of life (41). Nurses at EDs should rapidly identify the primary requirements, provide safety for the patients in ED and make them feel relaxed $(3,42)$. They should assess the reasons for presentation and inform the patients and their relatives in order to prevent the repetitive applications (41). They should refer the patients to the related department in order to meet their nursing requirements. Timely and accurate triage and qualified nursing care may increase the quality of life and safety of patients in EDs. In addition, a guideline for emergency admission and nursing care of cancer patients is necessary.

Especially, oncology and palliative care teams should make an appropriate discharge plan in collaboration with primary care services (home health care and family health care) in order to improve patients' coping with cancer and its symptoms and to prevent repetitive ED admissions.

In this respect, chemotherapy nurses should have the responsibility to guide the patients during the chemotherapy process. Patients and patients' relatives should be trained about the side effects and what they will do in case. Emergency care guidelines should be established to give better care to cancer patients admitted to ED. If home health care and hospice care services come common in Turkey, the frequency of ED visits may accordingly decrease. We also suggest that palliative care services should be expanded to include both home care and hospice care.

\section{Ethics}

Ethics Committee Approval: Ethical approval (50687469-1491-2725) was received from Institutional Review Board of the University of Health Sciences, Gülhane Training and Research Hospital for this study.

Informed Consent: It was taken.

Peer-review: Internally peer-reviewed.

\section{Authorship Contributions}

Concept: E.B., Y.K. Design: E.B., Y.K. Data Collection or Processing: E.B. Analysis or Interpretation: E.B., Y.K. Literature Search: E.B., Y.K. Writing: E.B.

Conflict of Interest: No conflict of interest was declared by the authors.

Financial Disclosure: The authors declared that this study received no financial support

\section{References}

1. Dedeli O, Fadıloglu C, Uslu R. A survey of functional living and social support in patients with cancer. Turkish Journal of Oncology 2008;23:132-9.

2. Vandyk AD, Harrison BM, Macartney $G$, et al. Emergency department visits for symptoms experienced by oncology patients: a systematic review. Support Care Cancer 2012;20:1589-99.

3. Bozdemir N, Eray O, Eken C, et al. Demographics, clinical presentations and outcomes of cancer patients admitted to the emergency department. Turkish Journal of Medical Sciences 2009;39:235-40.

4. Vallerand $\mathbf{A H}$, Templin T, Hasenau SM, et al. Factors that affect functional status in patients with cancer-related pain. Pain 2007;132:82-90.

5. Wells N, Murphy B, Wujcik D, et al. Pain-related distress and Interference with daily life of ambulatory patients with cancer with pain. Oncology Nursing Forum 2003;30:977-86.

6. Beck SL, Dudley WN, Barsevick A. Pain, sleep disturbance and fatigue in patients with cancer: using a mediation 
model to test a symptom cluster. Oncology Nursing Forum 2005;32:E48-55.

7. Koller A, Miaskowski C, Geest SD, et al. Supporting selfmanagement of pain in cancer patients: methods and lessons learned from a randomized controlled pilot study. Eur J Oncol Nurs 2013;17:1-8.

8. Kocak S, Ertekin B, Polat M, et al. Reasons For Oncology Patients In The Emergency Department Application. Sakarya Medical Journal 2012;2:16-20.

9. Yaylacı S, Topuzoglu A, Karcıoglu O. Clinical Characteristics and One-Year Survival of Cancer Patients Presenting to Emergency Department. Int J Hematol 2009;4:213-22.

10. Tsai S, Liu L, Tang S, et al. Cancer pain as the presenting problem in emmergency departments: Incidence and related factors. Support Care Cancer 2010;18:57-65.

11. Jocham HR, Dassen T, Widdershoven G, et al. Quality of life in palliative care cancer patients: a literature review. J Clin Nurs 2006;15:1188-95.

12. Cancer Control Knowledge into Action WHO Guide for Effective Programmes Palliative Care. http://www.who.int/ cancer/modules/en/ accessed 22/07/2013.

13. Mayer DK, Travers D, Wyss A, Leak A, Waller A. Why do patients with cancer visit emergency departments? Results of a 2008 population study in North Carolina. J Clin Oncol 2011;29:2683-8.

14. Kilıcaslan C, Bozan H, Oktay C, et al. Demographic properties of patient presenting to the emergency department in Turkey. Turk J Emerg Med 2005;5:5-13.

15. Barbera L, Atzema C, Sutradhar R, et al. Do patient-reported symptoms predict emergency department visits in cancer patients? a population-based analysis. Ann Emerg Med 2013;61:427-37.

16. Minami S, Yamamoto S, Ogata Y, et al. Emergency department visits after hours by lung cancer patients in japan. Support Care Cancer 2013;21:2443-51.

17. Ernst E. Prevalence of use of complementary/alternative medicine: a systematic review. Bull World Health Organ 2000;78:252-7.

18. Setoguchi S, Earle CC, Glynn R, et al. Testing cancer quality measures for end-of-life care. Effective Health Care Research Report 2010;21:1-45.

19. Yıldırım B, Tanrıverdi O. Evaluation of Cancer Patients Admitted to the Emergency Department within One Month before Death in Turkey: What are the Problems Needing Attention? Asian Pac J Cancer Prev 2014;15:349-53.

20. Ozdemir U, Tascı S. Psychosocial problems and care of chronic diseases. Erciyes University Journal of Health Sciences 2013;1:57-72.

21. World Health Organization, Noncommunicable Diseases Country Proşles 2011, http://whqlibdoc.who.int/ publications/2011/9789241502283eng.pdf accessed 14/07/2013.
22. Usta Yesilbakan O, Durmaz Akyol A, Cetinkaya $Y$, et al. Studying the symptoms that are being experienced due to treatment by the patients who receive chemotheraphy and their effects on the quality of life. Journal of Ege University Nursing Faculty 2005;21:13-31.

23. Yigit M, Sogut $O$, Yigit $E$, et al. The Relationship Between Anemia and Recurrence of Ischemic Stroke in Patients with Trousseau's Syndrome: A Retrospective Cross-Sectional Study. Turk J Emerg Med 2016;16:65-8.

24. Sogaard M, Thomsen RW, Bossen KS, et al. The impact of comorbidity on cancer survival: a review. Clinical Epidemiology 2013;5:3-29.

25. Tanriverdi O, Beydilli H, Yildirim B. Karagoz U. Single Center Experience on Causes of Cancer Patients Visiting the Emergency Department in Southwest Turkey. Asian Pac J Cancer Prev 2014;15:687-90.

26. Baser S, Erdur B, Turkcuer I, et al. Application to Emergency Department among Patients with Lung Cancer. The Journal of Academic Emergency Medicine 2008;7:21-4.

27. Considine J, Livingston $P$, Bucknall $T$, et al. A review of the role of emergency nurses in management of chemotheraphyrelated complications. J Clin Nurs 2009;18:2649-55.

28. Kuzeyli Yıldırım Y, Uyar M, Fadıllıoglu C. Cancer pain and its influence on quality of life. Pain 2005;17:17-21.

29. Yavuzsen T, Komurcu Ş. Evaluation of the fatigue symptom in patients with cancer and associated clinical problem. Gulhane Medical Journal 2008;50:141-6.

30. Gabriel J. Acute oncological emergencies. Nursing Standard 2012;27:35-42.

31. Ahn S, Lee Y-S, Lim KS, et al. Emergency department cancer unit and management of oncologic emergencies: experience in Asan medical center. Support Care Cancer 2012;20:220510.

32. Akcay D, Gozum S. Evaluation of the effect of education of chemotherapy side effects and home follow-up on the quality of life in patients with breast cancer given chemotherapy. The Journal of Breast Health 2012;8:191-9.

33. Yamagishi A, Morita T, Miyashita M, et al. Symptom prevalence and longitudinal follow-up in cancer outpatients receiving chemotheraphy. J Pain Symptom Manage 2009;37:823-30.

34. Gultekin M, Boztas G. Turkey cancer statistics. Public Health Agency of Turkey 2014;41-3.

35. Livingston PM, Craike M, Considine J. Unplanned presentations to emergency departments due to chemotherapy induced complication: opportunities for improving service delivery. Australas Emerg Nurs J 2011;14:62-8.

36. Courtney DM, Aldeen AZ, Gorman SM, et al. Cancer-associated neutropenic fever: clinical outcome and economic costs of emergency department care. Oncologist 2007;12:1019-26.

37. Jain PN, Parab SY, Thota RS. A prospective, non-interventional study of assessment and treatment adequacy of pain in the emergency department of a tertiary care cancer hospital. Indian J Palliat Care 2013;19:152-7. 
38. Subası N, Oztek Z. Unmet need in turkey: home care service. TAF Preventive Medicine Bulletin 2006;5:19-31.

39. Cataka B, Kılınc AS, Badıllıoglu O, et al. Profile of Elderly Patients Who Use Health Services in their Homes and inHome Care. J Public Health (Oxf) 2012;10:13-21.

40. Agra Varela Y, Sacristan Rodea A, Pelayo Alvarez M, et al. Relationship between quality of life and various models of home care in terminal oncology patients from a health area of madrid. Rev Esp Salud Publica 2003;77:567-79.

41. Unsar S, Yıldız Fındık U, Kurt S, et al. Home Care in Patients with Cancer And Symptom Control. Journal of Firat Health Services 2007;2:89-106.

42. Aydın Bektas H. The Importance of Functional Status in Person with Cancer. Journal of Anatolia Nursing and Health Sciences 2009;12:54-60. 